\title{
Risk of annuloplasty and patch use in infective endocarditis mitral valve repair
}

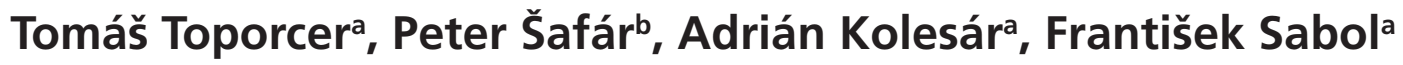 \\ a Department of Heart Surgery, Medical Faculty, Pavol Jozef Šafárik University and the Eastern Slovak Institute \\ for Cardiovascular Diseases Ltd., Košice, Slovakia \\ ${ }^{b}$ Department of Heart Surgery, Eastern Slovak Institute for Cardiovascular Diseases Ltd., Košice, Slovakia
}

ARTICLE INFO

Article history:

Submitted: 19. 11. 2018

Accepted: 17. 2. 2019

Available online: 27. 9. 2019

Klúčové slová:

Anuloplastický prstenec

Infekčná endokarditída

Náhrada mitrálnej chlopne

Plastika mitrálnej chlopne

Použitie záplaty

\section{SÚHRN}

Incidencia infekčnej endokarditídy je 3 až 10 prípadov na 100000 obyvatel'ov a rok. Medzi rizikové faktory tohto ochorenia patria ochorenia srdcových chlopní, implantácia chlopňových protéz, alebo iných cudzorodých materiálov, používanie vnútrožilových drog a imunodeficientné stavy pacienta.

Tridsatosem ročný pacient s anamnézou užívania vnútrožilových drog a plastiky mitrálnej chlopne pre infekčnú endokarditídu s použitím anuloplastického prstenca a záplaty, bol prijatý do nemocnice pre relaps infekčnej endokarditídy. Pri chirurgickej intervencii bola nájdená nepoškodená intaktná záplata mitrálnej chlopne a ložisko infekčnej endokarditídy v lokalite anuloplastického prstenca s abscesovou dutinou. Pacientovi bola vykonaná explantácia anuloplastického prstenca a implantácia mechanickej protézy do pozície mitrálnej chlopne.

Pokroky v technike záchovnej operácie mitrálnej chlopne zahrňujúce implatnáciu NeoChord a použitie záplat dovolujú využitie tejto metódy u stále väčšieho počtu pacientov s infekčnou endokarditídou. Použitie záplat sa ukazuje ako bezpečná metóda v tomto teréne. Použitie anuloplastického prstenca v teréne infekčnej endokarditídy ostáva kontroverzné. Ba čo viac, prezentovaná kazuistika v korelácii s publikovanými prácami poukazuje, že implantácia anuloplastického prstenca je možným rizikovým faktorom relapsu infekčnej endokarditídy.

(c) 2019, ČKS

\section{ABSTRACT}

The incidence of infective endocarditis is 3-10 per 100,000 people per year. Risk factors for this disease include heart-valve disease, the implantation of a prosthetic valve or intra-cardiac devices, drug use and patient immunodeficiency.

A 38-year-old drug-using man with a history of mitral valve surgery with patch reconstruction and annuloplasty ring implantation due to infective endocarditis was admitted to the hospital because of recurrence of mitral valve endocarditis. Surgery confirmed the unaffected patch in the posterior leaflet and the ring affected by an abscess cavity. Explantation of the annuloplasty ring and implantation of a mechanical valve prothesis was performed.

Advances in techniques of mitral valve repair, including NeoChords and patch use, make this procedure feasible for more and more patients with mitral valve infective endocarditis. The use of a patch appears to be a safe benefit for the patient. There is no clear opinion on the unconditional use of annuloplasty ring during mitral valve repair in the area of infective endocarditis. Moreover, the presented case in correlation with

literature presents annuloplasty ring as a risk factor for infective endocarditis relapse.
Keywords:

Annuloplasty ring

Infective endocarditis

Mitral valve repair

Mitral valve replacement

Patch use

Address: MUDr. Tomáš Toporcer, PhD., Department of Heart Surgery, Medical Faculty, Pavol Jozef Šafárik University and the Eastern Slovak Institute for Cardiovascular Diseases Ltd., Ondavská 8, 04001 Košice, Slovak Republic, e-mail: topyto@gmail.com DOI: 10.33678/cor.2019.043 


\section{Introduction}

Infective endocarditis (IE) is a potentially fatal disease with a yearly incidence of 3-10 per 100,000 people. ${ }^{1}$ In 1885, William Osler defined IE as possible to treat, and today this disease in clinically definable and treatable. ${ }^{2}$ In the 19th century, IE affected predominantly young adults with rheumatic heart valve disease. At the end of 20th century, the predominant group of IE patients included elderly with prosthetic valves and intra-cardiac devices. ${ }^{1,2}$ There is an increasing incidence of IE in young, drug-using people today. Moreover, young drug-using patients with implanted intra-cardiac devices are a double threat group of patients. The incidence of cardiac-devices IE showed a $210 \%$ increase in 15 years. ${ }^{3}$ Despite improvement in therapy for IE, the fatality rate has not significantly decrease during the last 40 years and in-hospital mortality is still about $20 \% .4,5$ Overall, $40-50 \%$ of patients with IE require surgery. ${ }^{1}$ If the mitral valve is affected, repair of the valve is more beneficial for the patient in comparison with replacement. 2,6-10 There is no clear opinion on the safety of using a repair technique in the field of IE. If repair is impossible, guidelines for the selection of the valves are also not clear in the literature. ${ }^{1,11}$

The case report shows the recurrence of mitral valve IE in a young drug-using patient. The work is focused on the safety of mitral valve repair (MVr) techniques and selection of a protheses type in the field of IE.

\section{Case report}

A 38-year-old man with a history of mitral valve surgery because of infective endocarditis and opiate addiction was admitted to a peripheral hospital because of fever of $39^{\circ} \mathrm{C}$, dyspnoea and Janeway lesions. Microbiological evaluation of his blood showed Staphylococcus aureus. Ultrasonography of the abdomen showed splenomegaly. Levels of C-reactive protein and procalcitonin were 360 $\mathrm{mg} / \mathrm{dL}$ and $2 \mathrm{ng} / \mathrm{mL}$. The patient was transferred to the Department of Cardiology of our institution because of suspicion of endocarditis. Study of the documentation showed that the patient had undergone annuloplasty of the mitral valve with repair of the posterior leaflet by pericardium because of IE and embolectomy from the brachial and ulnar artery 15 months before. Ultrasonography showed the recurrence of IE of the mitral valve, with mitral valve regurgitation (MR). Both cusps of the mitral valve were affected, and MR of grade II was recorded. Computer tomography recorded extensive spleen infarctions (Fig. 1). Urgent heart surgery was indicated because of embolization confirmed from the endocarditis deposit.

A standard midline sternotomy was performed. Afterwards, a cardiopulmonary bypass was established by separate cannulation of the superior and inferior vena cava, and the heart was arrested using anterograde cardioplegia. Surgical access to the mitral valve was prepared by right side atriothomy and incision of the atrial septum. Each cusp of the mitral valve was affected by endocarditis, while the pericardial patch was surprisingly unaffected (Fig. 2-4). An abscess cavity in the annulus of the mitral valve was recorded. Excision of the valve and the

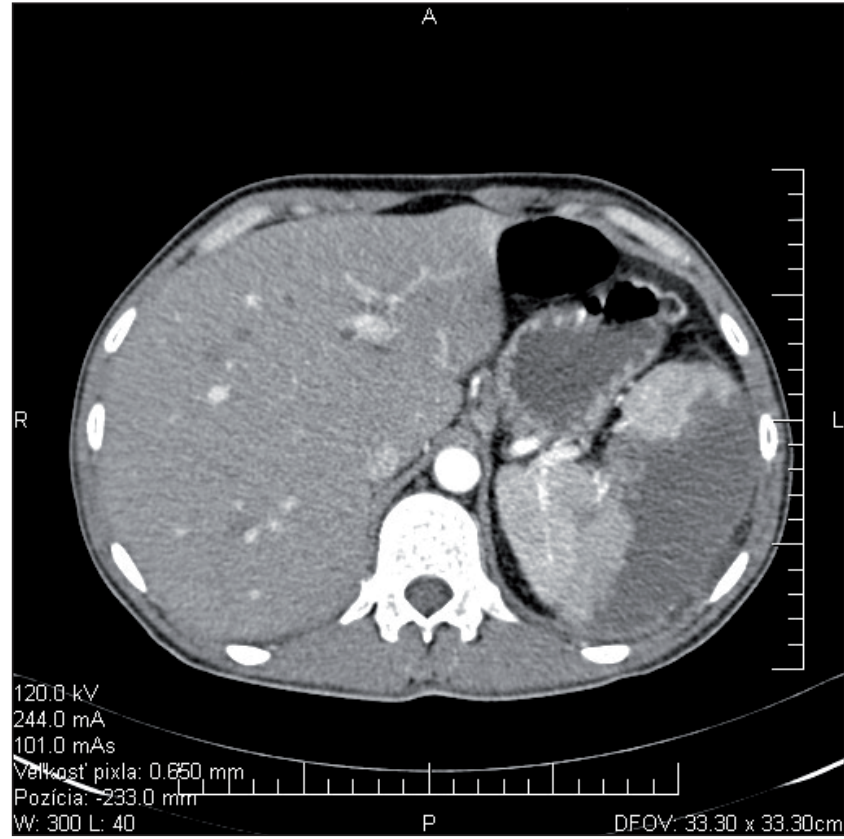

Fig. 1 - Computer tomography of the spleen with extensive spleen infarctions

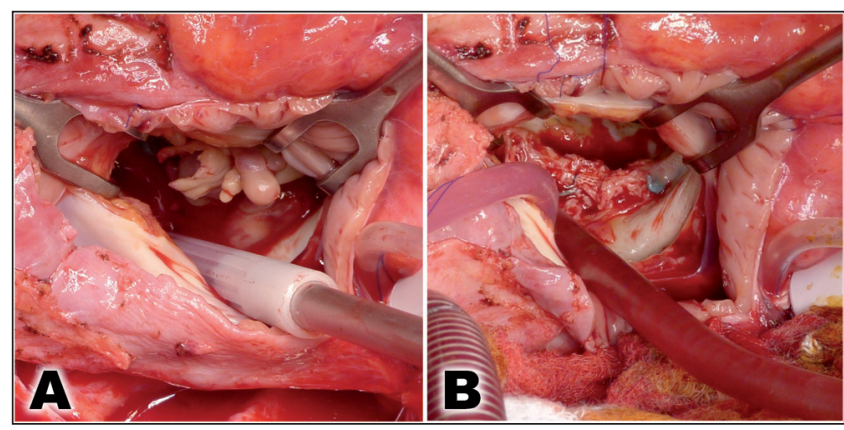

Fig. 2 - Perioperative picture of infective endocarditis of mitral valve

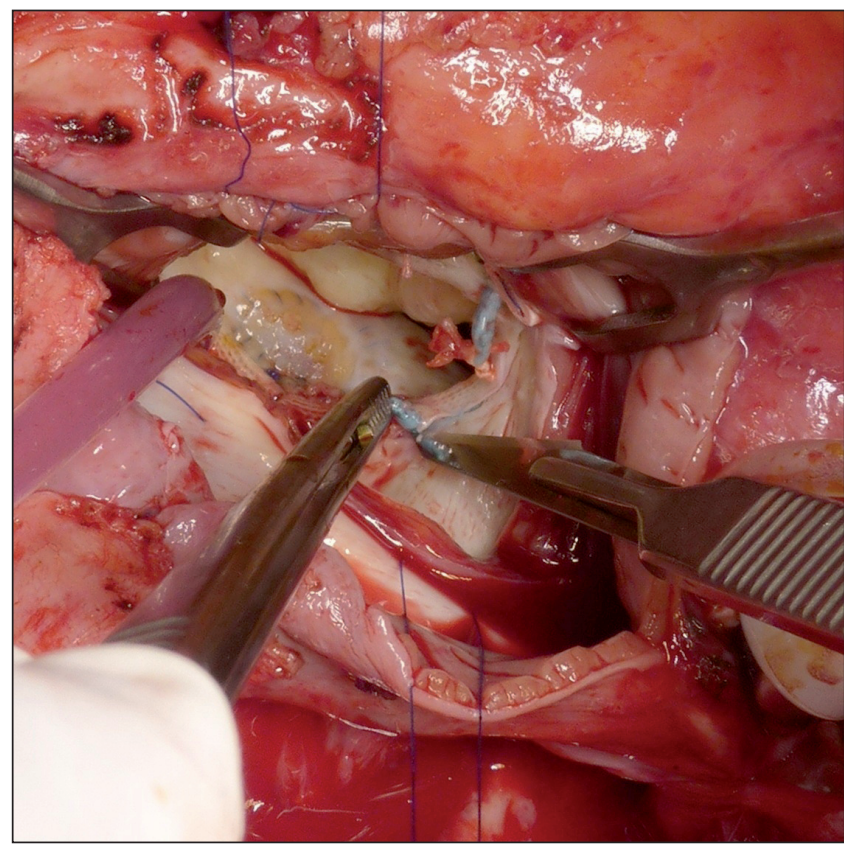

Fig. 3 - Perioperative picture of the unaffected pericardial patch 


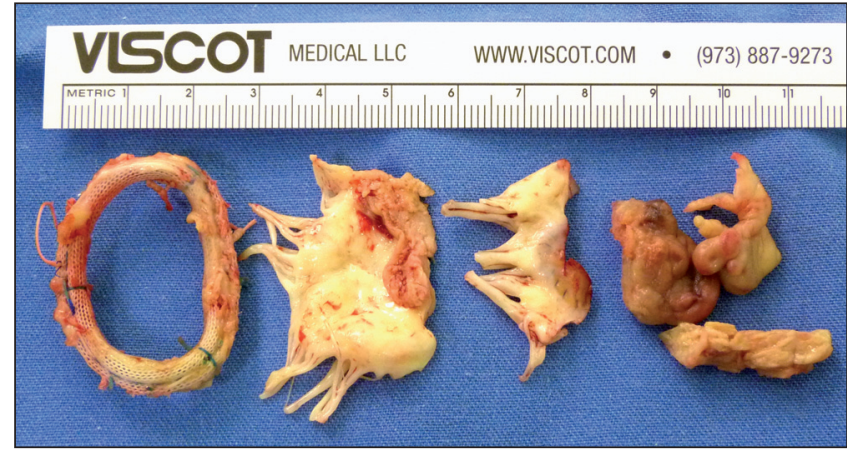

Fig. 4 - Explanted tissue of the mitral valve and an explanted annuloplasty ring

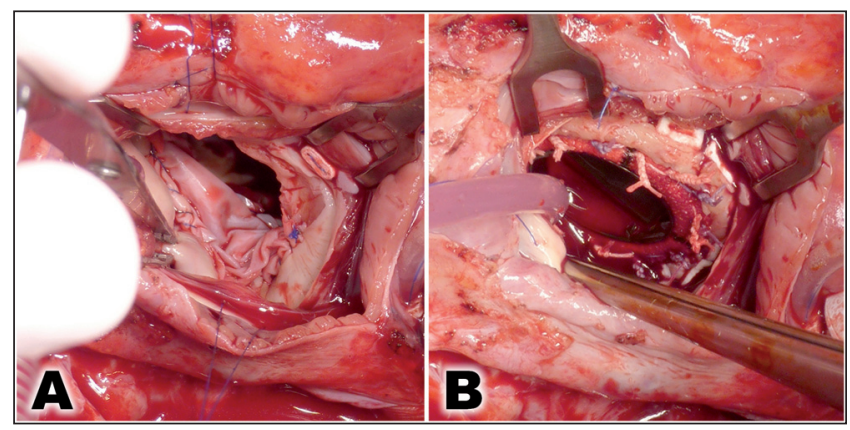

Fig. 5 - Perioperative picture of implantation of bovine pericardium (A) and a mechanical prosthesis (B)

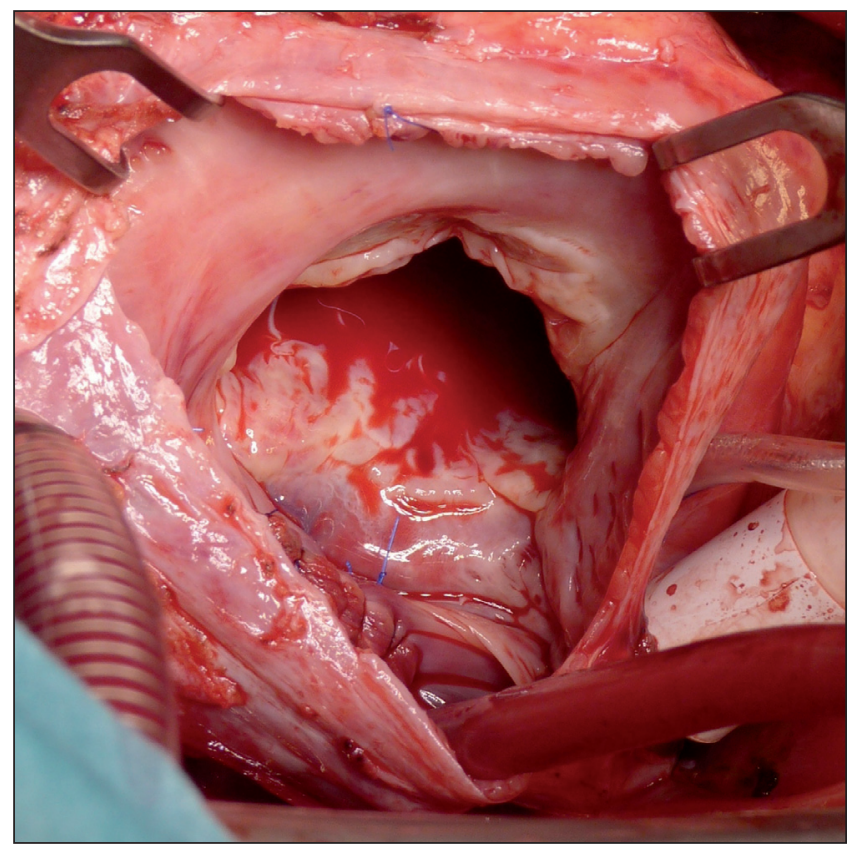

Fig. 6 - The unaffected tricuspid valve

annuloplasty ring was performed. The annulus of the mitral valve was repaired by implantation of a bovine pericardium, and a mechanical prosthesis (ATS No 25) was implanted (Fig. 5). No affection of the tricuspid valve was recorded (Fig. 6). Suture of the atrial septum and right atrium wall was performed. The cardiopulmonary bypass lasted 198 minutes, and the aortic clamping time was 146 minutes.
The postoperative condition was complicated by fever. Echocardiography did not show any endocarditis and only antibiotics therapy was applied. Antibiotic therapy was complicated by acute renal insufficiency, leading to forced antibiotic modification and shortening of its administration. On the twenty-ninth postoperative day the patient was discharged in good condition.

\section{Discussion}

Surgical intervention because of mitral valve IE can involve MVr or mitral valve replacement (MVR). In general, for non-infectious patients, MVr results in benefits from the point of view of perioperative mortality, preservation of ventricular function and a decrease in tromboembolic complication. ${ }^{12,13}$ MVR has been the gold standard in the treatment of mitral valve endocarditis. However, $\mathrm{MVr}$ avoids insertion of a prosthetic valve into infective tissue. ${ }^{8,12}$ Harky et al. published a metanalysis focused on a comparison of MVR and MVr in the field of IE. The study includes nearly 9000 patients and shows the short-term and long-term benefits of MVr in comparison with MVR. ${ }^{12}$ The authors also present the smaller risk of IE recurrence in the MVr group. Another study presents $90 \%$ freedom from IE recurrence after $\mathrm{MVr}$ at 5 years follow-up. ${ }^{14}$ It should be remembered that MVr in the field of acute IE may be difficult to enforce. On the other hand, MVr can be limited by the extent of tissue destruction, and earlier intervention helps to ensure valve reparability. Rostagno et al. present a $96.7 \%$ long-term survival rate after $\mathrm{MVr}$ if early surgery is indicated and only a small portion of valvular tissue is destroyed. ${ }^{6}$ Perrotta et al., in a single-centre study focused on IE of mitral valve, present an $86 \%$ versus $55 \%$ survival at 5 -years follow-up and $77 \%$ versus $41 \%$ survival at 10 -years follow-up for $\mathrm{MVr}$ versus the MVR procedure. ${ }^{8}$ Toyoda et al. show $68 \%$ survival for MVr and $53 \%$ survival for MVR at 12-year follow-up of IE patients. ${ }^{7}$ Lee et al. also conclude that MVr for IE has better perioperative results and lower rates of late mortality than MVR. ${ }^{15,16}$ Solari et al. present $88 \%$ and $81 \%$ freedom from reoperation 10 and 15 years, respectively, after $\mathrm{MVr}$ because of IE, which is a similar rate to the MVR group. ${ }^{9}$ Harky et al. present that $32 \%$ of 8,978 patients with mitral valve IE underwent MVr. ${ }^{12}$ Other studies have documented a rising share of $\mathrm{MVr}$ in IE patients from $10.7 \%$ to $19.4 \%$ during two decades. ${ }^{7,9}$ Our case also documents the safety of MVr in the field of IE under conditions of exclusion of IE relapse risk.

Advances in techniques of MVr, including NeoChords, patch use and annuloplasty, make the repair of this valve feasible for more and more patients., ${ }^{817}$ These modern techniques are also used for patients with IE, which leads to the fact that MVr is feasible in $80 \%$ to $85 \%$ of patients with mitral valve IE. ${ }^{9,10,18}$ Solari at al. present that survival after MVr because of IE is comparable with the survival after MVr because of degenerative disease. ${ }^{9}$ The authors compared a group of patients with mitral valve IE who underwent MVr with and without the use of a patch for mitral valve leaflet repair. The study present $85.7 \%$ and $75.4 \%$ freedom from reoperation in 10 and 15 years follow-up, respectively, after MVr with patch use, which is 
comparable with $\mathrm{MVr}$ without patch use. ${ }^{9}$ In the case presented herein the patient also underwent $\mathrm{MVr}$ with path implantation because of a defect in the posterior leaflet of the mitral valve. Nonetheless, recurrence of IE came about, and the patch in dorsal leaflet was not affected (Fig. 3). This fact, in correlation with a published study, confirms the safety of patch use in the field of IE. ${ }^{9}$

Annuloplasty is a widely and often used technique as part of the MVr procedure. More authors also use this technique if IE is presented. ${ }^{9,10}$ Nakamura et al. present that they did not hesitate to perform a semi-rigid type ring annuloplasty in the field of IE. ${ }^{10}$ Solari et al. present the use of the annuloplasty technique in $51 \%$ of patients with IE. ${ }^{9}$ On the other hand, Gardner et al. do not show the absence of annuloplasty during $\mathrm{MVr}$ as a risk factor for death, reoperation or MR relapse at 20 years follow-up in a group of 685 patients with degenerative MR. Moreover, the authors documented 4 cases of IE after MVr, while two of them were limited to the annuloplasty ring. ${ }^{13}$ The presented case also documents the affecting of the annuloplasty ring with an abscess cavity intimately close to the ring. An annuloplasty ring is intra-cardiac device which is connected with a higher risk of IE. ${ }^{2}$ The presented case shows that an intra-cardiac device, including an annuloplasty ring, is risk factor for IE not only during reendothelization during the first three mounts, but throughout the whole life of the patient. Rostagno et al. also present only one recurrence of IE after $\mathrm{MVr}$ - in an intravenous drug-user 11 months after surgery. ${ }^{6}$

Some older studies preferred using a biological protheses in the field of IE. ${ }^{2,11}$ However, in the American College of Cardiology and American Heart Association guidelines (2014) and in the European Society of Cardiology guidelines for IE management (2015) there is no strict definition of a prothesis type preference. ${ }^{19,20}$ Tao et al. published a metanalysis focused on the choice of a valve in the field of IE. ${ }^{1}$ The study includes more than 10 thousand cases and presented a higher mortality risk $(p=0.023)$ and earlier mortality risk $(p=0.033)$ in the group of biological protheses in comparison with the group of mechanical prothesis. The authors also recorded a higher risk of IE recurrence $(p=0.001)$ and risk of reoperation $(p=0.010)$ in the group of biological prothesis. There was no statistically significant difference in the parameter of embolism risk. ${ }^{1}$ The higher mortality risk in the group of biological valves could be caused by the higher age of the patients in this group in the more retrospective and prospective studies included in this metanalysis ( 54 versus 49 years; 62 versus 54 years and 63 versus 57 years, respectively). ${ }^{21-23}$ Two of these studies present a higher mortality rate for IE patients younger than 65 years after biological prothesis implantation in comparison with mechanical prothesis at one-year and five-year follow-up. ${ }^{21,23}$ Additional parameters are risk of reinfection, which is approximately $1.3 \%$ of patients per year after prothesis implantation because of IE, which is $8 \%$ to $27 \%$ at long-term follow-up. .,12 $^{12} \mathrm{Fe}$ doruk et al. present by univariate analysis a 2.68-times higher risk of IE recurrence after biological prothesis implantation in comparison with mechanical prothesis. ${ }^{24}$ The analysis was influenced by a higher incidence of intravenous drug users and HIV positive patients in the group with biological protheses implantation. ${ }^{1,24}$ Other studies present no difference in the risk of IE recurrence between biological and mechanical prothesis. ${ }^{16,25}$

\section{Conclusion}

Infective endocarditis is still a topical subject in cardiosurgery, with increasing incidence in young, drug-using and HIV positive patients. According to the published data and guidelines, MVr in the field of IE is favored whenever possible. Advances in the techniques of $\mathrm{MVr}$, including NeoChords and patch use, make MVr feasible for more and more patients with IE. The use of a patch appears to provide a safe benefit for the patient. There is no one opinion on the unconditional use of an annuloplasty ring during $\mathrm{MVr}$ in the field of IE. Moreover, the presented case, in correlation with literature, presents an annuloplasty ring as a risk factor of IE relapse. If replacement of the mitral valve is necessary, the use of biological in comparison with mechanical valve does not represent any benefits for patient with IE.

\section{Conflict of interest}

The authors declare no conflict of interest.

\section{Funding body}

article was supported in part by the Grant Agency of Ministry of Education, Science, Research and Sport of the Slovak Republic (VEGA 1/0660/16).

\section{Ethical statement}

The Independent Ethics Committee of the Eastern Slovak Institute for Cardiovascular Diseases, Ltd., confirmed that the case report is in compliance with the principles of the Declaration of Helsinki and ICH Guidelines for Good Clinical Practice and applicable regulatory requirements.

\section{Informed consent}

Informed consent for publication of pictures from surgery was obtained, and the records on consent are available for the editor.

\section{References}

1. Tao $E$, Wan $L$, Wang W, et al., The prognosis of infective endocarditis treated with biological valves versus mechanical valves: A meta-analysis, PLoS One 2017;12:e0174519.

2. Toporcer $T$, Kolesár $A$, Ledecký $M$, et al. Late infective endocarditis of an Amplatzer atrial septal device twelve years after implantation. Cor Vasa 2018;60:e174-e178.

3. Athan $\mathrm{E}, \mathrm{Chu}$ VH, Tattevin $\mathrm{P}$, et al., Clinical characteristics and outcome of infective endocarditis involving implantable cardiac devices. JAMA 2012;307:1727-1735.

4. Rajamannan NM. The risk of infective endocarditis in the 21st century. Indian Heart J 2013;65:452-453.

5. Slipczuk L, Codolosa JN, Davila CD, et al. Infective endocarditis epidemiology over five decades: a systematic review, PLoS One 2013;8:e82665.

6. Rostagno C, Carone E, Stefano PL. Role of mitral valve repair in active infective endocarditis: long term results. J Cardiothorac Surg 2017;12:29.

7. Toyoda N, Itagaki S, Egorova NN, et al. Real-world outcomes of surgery for native mitral valve endocarditis. J Thorac Cardiovasc Surg 2017;154:1906-1912.e9. 
8. Perrotta S, Frojd V, Lepore V, et al. Surgical treatment for isolated mitral valve endocarditis: a 16-year single-centre experience. Eur J Cardiothorac Surg 2018;53:576-581.

9. Solari S, De Kerchove L, Tamer S, et al. Active infective mitral valve endocarditis: is a repair-oriented surgery safe and durable? Eur J Cardiothorac Surg 2019;55:256-262.

10. Nakamura K, Hashimoto K, Sakamoto Y, et al. Safe Use of Glutaraldehyde to Repair the Destroyed Valve in Active Infective Mitral Valve Endocarditis, Circ J 2018;82:2530-2534.

11. Bedeir K, Reardon M, Ramlawi B. Infective endocarditis: perioperative management and surgical principles. J Thorac Cardiovasc Surg 2014;147:1133-1141.

12. Harky A, Hof A, Garner M, et al. Mitral valve repair or replacement in native valve endocarditis? Systematic review and meta-analysis. J Card Surg 2018;33:364-371.

13. Gardner MA, Hossack KF, Smith IR. Long-Term Results Following Repair for Degenerative Mitral Regurgitation Analysis of Factors Influencing Durability. Heart Lung Circ 2018 Oct 17. pii: S1443-9506(18)31952-8. doi: 10.1016/j. hlc.2018.10.011. [Epub ahead of print]

14. Mihaljevic T, Paul S, Leacche M, et al. Tailored surgical therapy for acute native mitral valve endocarditis. J Heart Valve Dis 2004;13:210-216.

15. Lee HA, Cheng YT, Wu VC, et al. Nationwide cohort study of mitral valve repair versus replacement for infective endocarditis. J Thorac Cardiovasc Surg 2018;156:1473-1483.e2.

16. Antunes MJ. Mitral valve repair versus replacement for infective endocarditis. What is better in the "real world"? J Thorac Cardiovasc Surg 2018;156:1471-1472.

17. Lazar HL. Mitral valve repair for patients with infectious endocarditis. Is it the procedure of choice for all patients? J Card Surg 2018;33:372-373.
18. Linhartová K, Beneš J, Gregor P. 2015 ESC Guidelines for the management of infective endocarditis. Summary document prepared by the Czech Society of Cardiology. Cor Vasa 2016;58:e107-e128.

19. Nishimura RA, Otto CM, Bonow RO, et al. 2014 AHA/ACC guideline for the management of patients with valvular heart disease: a report of the American College of Cardiology/ American Heart Association Task Force on Practice Guidelines. J Am Coll Cardiol 2014;63:e57-e185.

20. Habib G, Lancellotti P, Antunes MJ, et al. 2015 ESC Guidelines for the management of infective endocarditis: The Task Force for the Management of Infective Endocarditis of the European Society of Cardiology (ESC). Endorsed by: European Association for Cardio-Thoracic Surgery (EACTS), the European Association of Nuclear Medicine (EANM). Eur Heart J 2015;36:3075-3128.

21. Delahaye $\mathrm{F}$, Chu VH, Altclas J, et al. One-year outcome following biological or mechanical valve replacement for infective endocarditis. Int J Cardiol 2015;178:117-123.

22. Savage EB, Saha-Chaudhuri P, Asher CR, et al. Outcomes and prosthesis choice for active aortic valve infective endocarditis: analysis of the Society of Thoracic Surgeons Adult Cardiac Surgery Database. Ann Thorac Surg 2014;98:806-814.

23. Nguyen DT, Delahaye F, Obadia JF, et al. Aortic valve replacement for active infective endocarditis: 5 -year survival comparison of bioprostheses, homografts and mechanical prostheses. Eur J Cardiothorac Surg 2010;37:1025-1032.

24. Fedoruk LM, Jamieson WR, Ling $\mathrm{H}$, et al. Predictors of recurrence and reoperation for prosthetic valve endocarditis after valve replacement surgery for native valve endocarditis. J Thorac Cardiovasc Surg 2009;137:326-333.

25. Kim JB, Ejiofor Jl, Yammine M, et al. Are homografts superior to conventional prosthetic valves in the setting of infective endocarditis involving the aortic valve? J Thorac Cardiovasc Surg 2016;151:1239-1246, 1248.e1-2. 